\title{
Aura fractal, fins da arte e capitalismo primitivista
}

\author{
LEONARDO BERTOLOSSI
}

Leonardo Bertolossi é bacharel e licenciado em História pelo IFCS/UFRJ (2006), fez o mestrado em Antropologia Social no Museu Nacional/UFRJ (2010), e o doutorado na mesma área na FFLCH/USP (2015). No mestrado pesquisou com apoio CAPES e FAPERJ as políticas e poéticas de representação indígenas norte-americanas do NMAl, do Smithsonian Institute, em Washington D.C, Maryland e Nova York, com ênfase nas exposições de artistas contemporâneos indígenas norte-americanos. No doutorado pesquisou com apoio CNPq o circuito e o mercado primário de arte contemporânea

nos anos 80 e 90, com ênfase na geração 80, na Bienal de São Paulo, e no debate em torno da identidade e dos rumos da internacionalização da arte contemporânea brasileira e latino-americana. Foi professor substituto de Antropologia da UERJ (2013) e da UFF (2016-7), e foi curador da exposição de artes visuais "Uterutopias" no espaço A MESA. Desde 2013 vem ministrando cursos de extensão de Antropologia da Arte no CPC Casa de Dona Yayá da USP, no CCJF, na EAV/Parque Lage, na Casa do Saber Rio, e na Casa França-Brasil. Atualmente é pós-doutorando em Artes Visuais com apoio CAPES pelo PPGAV/EBA-UFRJ. 
"One shaft of light that shows the way

No mortal man can win this day

It's a kind of magic"

(Queen)

"Se Deus quiser

Um dia eu quero ser índio"

(Rita Lee)

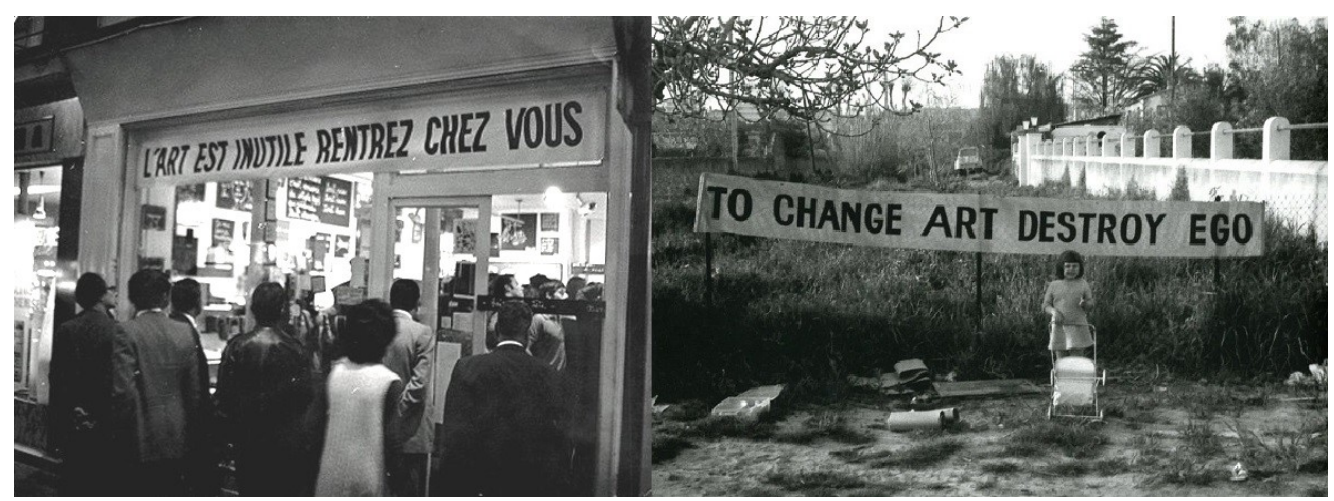

Figura 1. L'Art est Inutile Rentrez Chez Vous. Ben Vautier, 1971. Reprodução.

Figura 2. To Change Art Destroy Ego. Ben Vautier, 1968. Reprodução.

- RESUMO

Objetiva-se refletir sobre as relações entre as artes visuais e a antropologia a partir do texto seminal de Walter Benjamin sobre a aura para pensar sobre as finalidades e os fins da metafísica da arte no Ocidente diante dos diagnósticos de fim de mundo/fim da história da arte, e da vitória do espetáculo e da indústria cultural no capitalismo contemporâneo. O artigo apresenta alguns dos sentidos da arte no mundo ocidental e em especial no romantismo, avança sobre a crise e o fim dos modelos estruturais e cognitivos do pensamento artístico moderno, destaca o interesse pela política e pela vida, e se indaga sobre a retomada do primitivismo nas artes visuais e na antropologia contemporânea como redenção e renovação das mortes anunciadas.

\section{PALAVRAS-CAVE}

Antropologia da arte, aura, alma, tanatologia, primitivismo

\section{ABSTRACT}

The objective is to reflect on the relations between the visual arts and anthropology from Walter Benjamin's seminal text on the aura to think about the purposes and ends of the metaphysics of art in the West in the face of end-of-world/end-of-art history, and the victory of spectacle and cultural industry in contemporary capitalism. The article presents some of the meanings of art in the Western world and especially in Romanticism, advances on the crisis and the end of the structural and cognitive models of modern artistic thought, highlights the interest in politics and life, and 
inquires about the resumption of Primitivism in the visual arts and contemporary anthropology as redemption and renewal of the announced deaths.

\section{- KEYWORDS}

Anthropology of art, aura, soul, thanatology, primitivism

\section{Estilhaços estéticos}

Ars longa, vita brevis, teria afirmado o médico grego Hipócrates esse famoso aforismo popularizado pelo poeta romano Sêneca. Se a vida é sempre curta memento mori -, a busca humana de deixar um legado através da arte engendra paixões e profissões de fé. As escatologias e o medo do fim voltaram à moda nos debates e exposições em artes visuais recentemente, mas o campo artístico, a despeito dos anúncios de incerteza, nunca teve tanta vitalidade.

Dos anos 80 para cá, o sistema artístico internacional passou por diversas transformações e a consolidação de suas instituições. Dentre eles, uma profusão de novas bienais internacionais, feiras de arte contemporânea de diversos segmentos, novos colecionadores e a multiplicação de galerias de arte por todos os continentes. Tal cenário, no entanto, não se deu de forma homogênea e estável.

Diagnósticos de crise e as oscilações do setor, aliadas ao panorama da globalização e suas hierarquias desiguais, colaboraram para a manutenção de certo "mal-estar constitutivo" do campo, antes preocupado em afirmar um sentido humanista e um papel social e político para as artes, e agora às voltas com o dilema de sua espetacularização e sua provável serventia ao capitalismo neoliberal. A "magia da arte", então, originalmente presente na filosofia kantiana e seus ecos em autores como Walter Benjamin e em Lévi-Strauss, começa a se esfacelar e se fractalizar numa legião nômade de agentes intermitentes e errantes, uma "guerra de magia" cujo suposto vilão, o mercado, parece ameaçar o "belo" papel da arte e sua ontologia historicamente preconizados pela filosofia ocidental.

Críticos de arte e curadores sugerem uma revisão analítica e descolonial dos modelos narrativos e cognitivos de ordenar a história da arte e seus objetos artísticos. A antropologia se torna disciplina privilegiada para acessar alteridades alhures e experiências diferenciadas que permitam renovar as políticas e poéticas da arte ocidental, e também, ao final, a categoria conceitual da vida surge como horizonte afirmativo da permanência do mito artístico e de sua finalidade resistente e potente diante dos diagnósticos do seu fim.

A aposta conceitual aqui é a de que há uma "guerra de magia"1 entre o

\footnotetext{
${ }^{1}$ Concebo magia neste artigo a partir do seminal ensaio de Marcel Mauss (MAUSS, 2003) que a entende por ação e relação social, sistema de crença, normatização e hierarquização de saberes, papéis sociais e poderes, forma de comunicação. A eficácia da magia exige prescrições determinadas que envolvem uma concepção metonímica dos objetos envolvidos (simpatia etc.), assim como o controle dos saberes e das relações através de uma lógica de mistério e segredo dos elementos envolvidos. Me afasto, no entanto, do aspecto evolucionista deste autor, que supõe que a religião e seus mediadores, e a ciência, seriam transformações complexas e mais avançadas da magia. Entendo magia a partir de uma perspectiva latouriana (LATOUR, 1994), como um conhecimento passível de ser simetrizado com a ciência ocidental.
} 
sentido originário da arte (e a tentativa de manter a ficção ocidental que a justifica), e a "magia capitalista" sedutora e alienante, revisitada. Se Marx já nos falava das inversões perversas do capital no capítulo fulcral sobre a mercadoria, Benjamin sugeriria que o capitalismo era encantado tal qual uma religião. Agora o capitalismo é diagnosticado como uma feitiçaria repleta de alternativas infernais e "mãozinhas invisíveis" (STENGERS, 2007) que nos tornam cada vez mais reféns de suas estratégias zumbificadoras; um "capitalismo artista" (LIPOVETSKY; SERROY, 2015) que expande o campo artístico para arenas imprevistas e estetiza a tudo e a todos. Não pretendo aqui reificar esses diagnósticos, mas entendê-los a partir do debate dos filósofos, críticos de arte e antropólogos aqui evocados, assim como indagar sobre suas limitações e o aspecto vago e genérico de suas abstrações se acompanharmos de dentro ou de perto os diferentes atores e contextos no sistema internacional das artes.

\section{A dança das auras}

Considerando-se a hipótese de uma "guerra de magia" que orienta esta reflexão, pensar o conceito de aura nas artes visuais é fundamental. Walter Benjamin (BENJAMIN, 1994) ficou consagrado pelo ensaio já clássico (em suas diferentes versões) acerca da obra de arte na era da reprodutibilidade técnica. Se Benjamin se indagava sobre a autenticidade e os dilemas da arte do seu tempo diante da fotografia e do cinema, do Mickey Mouse, da sociedade de consumo, e da indústria cultural insurgente, poderíamos questionar a pertinência de sua sugestão sobre o enfraquecimento da aura nos dias de hoje.

Como pensar a atual vitalidade das imagens da cultura de massa na produção e profusão atomizada de atores em intensa circulação e valoração? Como não continuar reificando um entendimento sobre a aura apenas através de uma interpretação moderna que inscreve o objeto/experiência artística em rituais de contemplação e em uma atmosfera de sagrado/segredo? O cenário contemporâneo não desafiaria aos mitos artísticos ocidentais sobre o papel da arte e da revelação de um sentido profundo, ou ainda da crença em uma subjetologia ${ }^{2}$ íntima de um gênio romântico que anunciaria o porvir? Qual a "verdade da arte" nestes tempos espetaculares e difusos, cuja ética das imagens nas redes sociais contemporâneas seria outra diferente da época de Benjamin? O que pensar do esgarçamento da vida privada tornada pública nas redes sociais através das imagens, ou ainda do produtivismo e do consumismo efêmero e desenfreado das mesmas através da publicidade? Seria esse panorama geral uma das faces artimanha do capitalismo artista, de que nos fala Gilles Lipovetsky e Jean Serroy (LIPOVETSKY; SERROY, 2015)?

Se acompanharmos o debate sugerido pela filósofa Anne Marie Gagnebin (GAGNEBIN, 2014) sobre a relação entre arte e vida em Benjamin e em Adorno, a

\footnotetext{
${ }^{2}$ Penso o conceito de subjetologia a partir do antropólogo Marshall Sahlins, que difere teorias da cultura superorgânicas cuja contribuição e agência dos sujeitos é mínima, como na teoria foucaultiana do poder, as quais ele chama de "leviatanologia"; de teorias da cultura que focam no indivíduo como agentes privilegiados da ação social e que encarnariam e performatizariam super entidades culturais, o que ele chama de "subjetologia" (SAHLINS, 2006, p. 133-148). Para o antropólogo, leviatanologia e subjetologia encontram-se em eterna oposição, e poderíamos dizer, portanto, que o mito ocidental do gênio romântico trata-se de uma subjetologia. Para uma crítica da genialidade romântica, ver também o ensaio do sociólogo Norbert Elias sobre a vida e a obra de Mozart (ELIAS, 1995).
} 
saída e sugestão benjaminiana é positiva e elogiosa. Com o individualismo heroico em xeque, com o esgotamento das formas burguesas de produção e de difusão artística, a arte sairia do registro "missionário" de uma revelação consagrada, da liquidação do eu, de transporte, abalo profundo, e de uma completude (como os sentidos da estética em Kant), para uma relação irônica, lúdica e desalienada pelo humor e pela dispersão como forma de resistência política. Se Adorno defende uma arte longe da vida para pensar as tensões entre esses supostos níveis epistemológicos-ontológicos diferenciados (para manter a potência), Benjamin preconiza uma arte que se volte ao mundo coletivo para lê-lo a contrapelo, que subverta as realidades sociais desiguais dos proletários, uma arte que saia do registro ótico e se torne jogo tátil.

Poderíamos dizer que o tema da aura segue reinventado também na antropologia através de um conceito correlato, o de alma. Antropólogos sociais de diferentes tradições nacionais, sobretudo após a redescoberta do animismo nos anos 90, reinvestem na aura/alma e em sua magia ao falarem de pessoas no mundo ameríndio e melanésio através de categorias como agência, redes transhumanas, vida e meio ambiente. As obras de arte não mais seriam a metáfora reduzida e traduzida da profusão e multiplicidade de uma interioridade genial artística, e portadora de um sentido crítico e prospectivo. Tampouco seriam objetos de contemplação, estética transcultural . Mais como pessoas, as obras de arte estariam vivas, seriam a presença metonímica de uma multiplicidade de agentes enredados, um "pandemônio" de vidas encarnadas numa determinada experiência, processo ou objeto partiIhado e completado/acionado na relação com outrem.

Se é antropólogo Alfred Gell (GELL, 1998, 2001) quem ficaria famoso por esta abordagem peirciana sobre o artístico que entende obras de arte como armadilha cognitiva, como pessoas e mentes em comunicação, é Bruno Latour (LATOUR 2008) quem nos ajuda a pensar os impasses e clashs entre diferentes redes artísticas mobilizando movimentos, "iconorragias", poderíamos dizer, deslocamentos entre convenções e invenções, se pensarmos nos termos de Roy Wagner (WAGNER 2010). Em seu projeto crítico de refundar a modernidade e dar cidadania aos híbridos, Latour (LATOUR 1994) trouxe considerações importantes sobre como alterar diferenças de tamanho entre diferentes ontologias e aproximá-las simetricamente.

No esteio deste pensamento, sua tentativa de propor uma teoria das imagens que escape ao desconstrutivismo e ao nilismo nos é interessante para pensar os incessantes movimentos da arte contemporânea em seu gosto iconoclasta. Se seguirmos com Latour, tais fluxos auráticos dos diferentes agentes animados do mundo da arte nos parecem mais "iconorrágicos", cascata de imagens, desfiguramento e (re)figuramento, "destruições criativas". Mas essa "dança das auras" em profusão não teria um efeito às avessas, para dentro, um voltar-se contra o feiticeiro? E quando o prognóstico de fim atinge a finalidade? E quais as finalidades da arte?

\footnotetext{
3 Entre 1989 e 1993 aconteceu na Universidade de Manchester, coordenados por Tim Ingold, uma série de debates sobre temáticas concernentes à antropologia clássica e contemporânea, tais como a pertinência da permanência dos conceitos de sociedade, cultura etc. Um deles, ocorrido em 1993, se ateve ao problema da estética como categoria transcultural. Partidários da etno-estética como Howard Morphy e Jeremy Coote defenderam que o conceito de estética é aplicável a povos extra-modernos, que os seres humanos são sensíveis a determinados objetos considerados belos e/ou artísticos. Joanna Overing e Peter Gow, por sua vez, se posicionaram contra a ideia de que estética é uma categoria transcultural ao relatarem o aspecto político e histórico deste termo, associado ao capitalismo e ao romantismo europeu e fora das lógicas cosmopolíticas indígenas, por exemplo. Para se inteirar deste debate ver Weiner et alli (WEINER, 1996).
} 


\section{Arte e euforia}

Em nossa antropologia nativa ocidental ${ }^{4}$, diversos "nativos filosóficos" de diferentes áreas disciplinares se puseram a refletir sobre os sentidos da arte. $\mathrm{O}$ intuito aqui não é fazer um inventário dos expoentes principais, mas apenas evocar algumas "entidades privilegiadas" por terem afinidades com a temática problematizada.

De início, poderíamos nos lembrar de Platão, para quem a arte era um saber perigoso e ilusório, reino da aparência e da imitação, uma produção de segunda categoria, réplica piorada do mundo da experiência, illusio corruptora das faculdades sensíveis humanas. Adiante, e na direção oposta, Kant sugere que a arte não é um charlatanismo, mas aquela que nos permite sair de nós mesmos, de nosso solipsismo. Com a estética kantiana o sujeito outrora cindido entre o real e o ideal se reencontra, o mundo passa a ser possível e não lhe é indiferente. Kant hierarquiza razões, e em sua misoginia, a estética é a razão feminina, aquela das sensações, que em muito se distancia das razões pura e prática. Mas a estética permite o eu ir além de si mesmo, produzir um conhecimento afetivo, intuitivo e intersubjetivo, uma humanidade partilhada.

Ao contrário da mercadoria e a alienação e objetificação que produz de nossa força de trabalho, conforme Marx (MARX, 1983), o objeto estético para Kant é aquele que nos permite nos comunicar com outros sujeitos, que nos permite alçar alguma liberdade, e suprir os vazios da esfera moral e política na razão prática, regulando-a. Terry Eagleton (EAGLETON, 1993) afirma que a estética kantiana supõe uma modalidade de conhecimento cujo entendimento e comunicabilidade entre os entes se dá num nível pseudo-cognitivo, pré-referencial e acidental, uma duplicação da estrutura da natureza na estrutura do sensório.

No entanto, se o belo pode ser entendido como aquilo que é tangível, como a completude do sentido, como a união eufórica do eu narcísico no outro; o sublime em Kant é da ordem da angústia e do mal-estar porque intangível e produtor de uma crise de identidade. Se o belo nos devolve ao útero, um fechamento feminino do imaginário, o sublime nos arremessaria na masculinidade militar. A estética sublime desafia a razão pura, nos devolve para nós mesmos produzindo mal-estar, consciência da incompletude, mas também o reconhecimento da autonomia do sujeito.

Subvertendo o liberalismo estético kantiano, para quem o gosto é altruísta e desinteressado, uma subjetividade sem sujeito, Adorno considerará a estética o necrológio da arte. Adorno defende a estética e o papel da arte como aquelas que problematizem a vida e a cultura, subvertendo o elogio de uma autonomia enganosa, já que a liberdade de uns é a escravização de outrem. A arte deve lutar contra ela mesma, ser uma forma de resistência iconoclasta às imposições sociais, uma alternativa ao pensamento. E para isso ela deve recusar a si própria, impor caos na ordem, ser um "encantamento desencantado", afirma (CHAIA, 2007, p. 35).

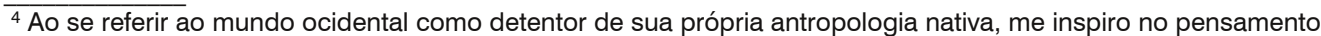
de Marshall Sahlins (SAHLINS, 2004, p. 563-619), um dos que concebeu as diferenças intensivas do Ocidente desta maneira em artigos como "A tristeza da doçura ou a antropologia nativa da cosmologia ocidental."
} 
Adorno parece resgatar um pensamento comum aos primeiros românticos, como Hölderlin e Schelling, para quem não há comunhão entre o sujeito e o objeto. Embora esses autores do primeiro romantismo, dentre outros nomes como Schiller e Schlegel, sugerissem uma aproximação da experiência estética com a febre amorosa, um jogo entre entendimento e imaginação, intuição e intelecto, todos estes concordam que tal experiência tem limites diante dos anseios humanos de reencontrar-se com o paraíso perdido das mitologias judaico-cristãs, de sair da caverna de Platão, ou reencontrar-se com o Absoluto hegeliano, pauta do debate romântico.

A filosofia para poder ser tampouco outro necrológio deveria ser tornar arte, poesia, afirmam os românticos mencionados, considerando-se que a arte é o "cerne da humanidade", afirmavam, nos mostra Pedro Duarte (DUARTE, 2011). A arte estaria assim entre poesia e filosofia, potência de vida. E qual o lugar do artista para essa filosofia? O artista era o gênio, o filho predileto da natureza, afirmaria Kant. Misto de força natural/possessão divina com reflexão intelectual, espontaneidade e cultura constituída, o artista seria assim aquele instrumento inconsciente da criação, detentor de um "dom natural" que só seria efetivamente potencializado com a gestão e o cultivo de um gosto que permitiria a expressão de tal faculdade criadora, sugere Schlegel. Como pensamento em jogo, a arte seria a expressão mais singular do humano, da vida e da liberdade expressa através da regularização do gênio; e o artista, o tradutor da natureza e do inconsciente, criador e pensador simultaneamente.

É Claude Lévi-Strauss o ventríloquo loquaz que atualiza essas versões morais sobre a finalidade da arte e sua justificativa como mito do melhor do humano. $\mathrm{O}$ antropólogo francês em seu desejo universalista de compreender as elaborações do pensamento em suas diferentes versões, viria a sugerir que é a arte, tal qual o mito, quem permite os atravessamentos, criatividades e inter-tradutibilidades culturais. O reino da arte é aquele marginal, liminar, sem pureza nem canto, mas esquina e avesso, entre bricolages que reinventam estruturas milenares, e aberturas metafísicas, engenhocas científicas que estouram as cadeias relacionais em seu desejo de flecha e de além.

É da estrutura do artístico ser aquele que realiza metonimicamente presentificações da "coleção cósmica" no "souvenir dos objetos", modelos reduzidos, sínteses eficazes que comunicam, deformam e atualizam as topologias virtuais do pensamento. Como significante flutuante (LÉVI-STRAUSS, 1989, 2003), a arte tem por função fazer o elo já descrito em Hegel, entre a sensibilidade imediata e o pensamento ideal. Tal dicotomia desponta em Lévi-Strauss como pensamento que pensa, mito da mitologia, música que estoura e desafia representações narrativas. Se poderia ainda pensar que a arte em Lévi-Strauss é algo kantiana, se dá num nível pré-cognitivo, inconsciente. Não é, no entanto, extrato inferior ou subconsciente, pensamento pré-lógico como supôs o antropólogo Lévy Bruhl, mas possibilidade primeira de criação, função simbolizante, natureza humana.

No entanto Lévi-Strauss parece soar platônico quando sugere que a literatura ou a fotografia são artes menores, de segunda categoria, porque estariam num registro documental, da replicação do mundo (NOVAES, 1999). Se para o autor a música está cheia de mitos e de aura, a fotografia e a literatura seriam produções desalmadas, desanimadas. Ele sugere também, reinventando espectros kantianos e românticos, que a arte e a experiência estética embora permitam um humanismo 
partilhado, deve transcendê-lo, evitar o embotamento narcísico, e se reconciliar com a natureza, que julga bela. Lévi-Strauss afirma, por exemplo, que a beleza de uma flor, de um mineral ou de um inseto são tão expressivas quanto uma pintura de Rembrandt ou de Tintoretto (ERIBON; LÉVI-STRAUSS, 2005, p. 246).

E essa é a beleza da arte como expressão do humano, sua finalidade maior, afirma o autor, para quem a maior perda da humanidade seria a das obras de arte e não a de séculos de história (LÉVI-STRAUSS, 1997, p. 139-140). Se a história é a metafísica humana ocidental questionada pelo autor em sua conversa com o filósofo Jean Paul Sartre, a arte, como encarnação da natureza e dos mitos, é aquela que permite a vida e um humanismo expandido. Se o humano ensimesmado está fadado à morte, o que pensar então da arte como sua mais sublime encarnação?

\section{O canto do cisne}

Era, portanto, preciso sair do quadro e do cubo branco. Se nessa direção crítica os anos setenta foram os anos da contracultura, da tropicália, do desbunde, da desmaterialização da obra de arte, da crença na revolução e na subversão do capitalismo, da utopia comunista e da luta contra as ditaduras latino-americanas; os anos oitenta foram "anos de ressaca" e de anúncio da vitória imperialista, queda do muro e das metafísicas modernistas, anos cínicos e narcísicos porque hedonistas e autorreferidos, disseram alguns críticos. Mas foram também anos de abertura e novas aventuras, do questionamento da obrigação de vanguarda, do retorno à pintura e da assunção do mercado, e do reconhecimento de uma arte que dialoga com o outro na direção de um estetismo multicultural, antes proletário e agora étnico.

As artes visuais agora não mais tinham por missão interferir na vida política de modo a resistir e subverter as estruturas de poder vigentes no Estado, no mercado e nas instituições artísticas. O artista não mais precisava deixar um legado e poderia transitar e experimentar diferentes passados e presentes, imaginar outros futuros micropoliticamente. Retornar à pintura foi visto como um retorno ao prazer e à festa, como o fim da tensão dos anos de chumbo, como possibilidade de recomeçar do zero, disseram nomes como Achile Bonito Oliva, "pai" da transvanguarda italiana. Morria a pretensão da arte revolucionária, surgia assim um novo horizonte (BERTOLOSSI, 2014).

Marisa Flórido (CESAR, 2016) sugere que essa cantilena saturnina no campo artístico não é algo novo. A morte da arte ocidental foi algo fractal, um fim de mundo anunciado e revisitado ao longo do século XX. O gosto pelo apocalipse estaria presente em momentos diversos. Na ruptura dos modernos com os românticos e com os antigos, nos manifestos, no dadaísmo, na arte abstrata e de cunho universalista e construtivista contra o realismo e o figurativismo, na pop arte e o reconhecimento do mercado, nas neovanguardas e no elogio do corpo e do espaço contra o sacro cubo branco e seu universalismo racionalista racista em tempos póscoloniais... Além da arte todos pareciam morrer ao seu redor. Nietzsche mata Deus, Barthes ao autor, Baudrillard ao real, Lyotard ao sujeito, Fukuyama a história, Arthur Danto e Hans Belting, por fim, põem fim à arte e à sua história.

Tal tanatologia tem várias faces neste debate e transcende ao imaginário da morte como um desaparecimento súbito. Exaustão, perda de finalidade e de identidade, fragmentação diante das contingências, profanação das verdades 
consagradas. Dentre elas, afirma Arthur Danto (DANTO, 2006), a perda da confiança na grande narrativa mobilizou a sugestão de uma arte pós-histórica, a afirmação de um pastiche híbrido e nômade, irônico, entrópico e desordenado para além de uma linearidade tangível em estilos. Tal mal-estar já estaria posto na crise após o pós-expressionismo abstrato, quando as ideias de arte e obra artística se perderiam no fluxo da vida; tudo é arte, nada é arte.

A arte, tal como um "objeto ansioso" que sugere Harold Rosemberg (ROSEMBERG, 2004), se torna vagante e cada vez mais imagem, panfleto, evento e cultura. A obrigação da vanguarda se despotencializa, o invólucro se perde, tudo é artificável. Rosemberg falaria ainda do artístico como um centauro, metade a obra, metade um texto que a traduza (p. 95). O Museu de Belas Artes se torna uma ruína com a chega dos "neo-primitivos" globalizados, os "impuros" pedem cidadania e a embalagem artística sai de cena, o desejo do real insurge como gozo possível diante da perda da aura original...

Se Benjamin elogiava a possibilidade de uma arte sem aura como espaço de jogo e subversão, em Danto a morte da arte é o reconhecimento de que a arte contemporânea é a antítese do gênio romântico e do panfleto moderno, é arte sem materialidade, sem objeto, sem sujeito, sem humanidade. Com a "queda do céu artístico", o desejo se sobrepõe ao real que recai sobre o corpo ciborgue das cirurgias estéticas, sobre o laboratório de micropartículas e o genoma, e sobre a diferença política como identidade tribal desigual de raça, de gênero, de sexualidade. Há a busca do resgate de um eu cada vez mais sem rosto definido no contemporâneo, na tentativa de superar o fim dos formalismos. Com o esvaziamento das pretensões morais da arte ocidental, os artistas se tornam professores universitários diplomados, os objetos artísticos não mais são apenas colecionados e contemplados, mas refletem também estilos de vida, são commodities nas vitrines luxuosas da sociedade do espetáculo.

Mas existem ainda outros renascimentos. No mundo pós-Muro de Berlim, as obras de arte em seu trânsito desvairado pelas novas feiras, museus e bienais do planeta acenariam para uma nova geopolítica relacional, outras topografias do campo artístico e relações transnacionais despontam. Se os manifestos modernistas se tornariam a crítica de arte neovanguardista dos anos 60, essa última agora é compactada e transmutada nas relações e pesquisas desenvolvidas pelos curadores e suas muitas exposições. Curadores, por sua vez, como os novos egos geniais e prestigiados no campo, passam cada vez mais a atuar como consultores de investimentos no mercado de arte.

Da poesia ao raio $\mathrm{X}$, do luxo ao fardo, da história da arte à teoria da arte, as artes visuais ocidentais cada vez mais se encarariam num espelho estilhaçado, sem grandes pretensões teleológicas e vanguardistas, acossadas por "vozes bárbaras" multiculturalistas ameríndias, africanas, asiáticas e aborígenes clamando visibilidade e representação de suas múltiplas histórias silenciadas, objetificadas, expropriadas... À quem pertencem e se endereçam as artes visuais se torna o novo grito de guerra que retoma tensões entre ideologias holistas e individualistas, iluminismo e romantismo, arquivo e dispersão, identidade e multidão. Vanguardas são domesticadas, tribais incluídos de forma colonizada e subserviente, o mito da aldeia global segue ao lado da manutenção das hierarquias glocais. É possível tropicalizar o norte? Será o Sul artístico apenas o estereótipo do feminino, antropofágico e tropical? 
Como "dar o fora" e voltar-se para dentro de modo a aparelhar os equipamentos culturais falidos de dentro de casa e reinventar os dispositivos conceituais artísticos sem colonizar ou ser colonizado ${ }^{5}$ ?

Neste melting-pot de angústias, o historiador Hans Belting (BELTING, 2012) destaca ainda a vitória do design, o elogio do cotidiano, o trânsito entre alta e baixa cultura, entre produção e reprodução, ready-made e ready-remake, o kitsch e as paródias da cultura como auto-derrisão da arte, o protesto/panfleto que vira publicidade e vice-versa, o presentismo que vira historicismo (habeas corpus da arte) e vice-versa, a arte que vira antropologia (identidade cultural) e vice-versa, o fim da era da arte como fim da era dos museus (que se tornam shoppings e centros culturais)... A ruideira infernal dos replicantes, os zumbis performáticos e a prêt-à-porterização estética desenfreada e que poderia ser aproximada do imaginário das amarras do micropoder foucaultiano... Para onde vamos? Há alguma saída?

\section{Quem mexeu na minha aura?}

À guisa de conclusão deste sobrevoo sobre as transformações da aura, os fins/finalidades e as mortes da arte nos temas, problemas e diagnósticos recentes, pretendo evocar algumas das alternativas em debate e o renascimento de estratégias modernas diante dos "grandes vilões" difusos e tornados espantalhos - o mercado de arte e o capitalismo.

Ao lado da profusão neonarrativa da arte dos anos noventa, da redescoberta do eu e do corpo de forma fáustica e high tech, do cinismo pós-modernista, e da melancolia festiva dos anos oitenta, desponta ainda e resistente uma arte neo-setenta, a(r)tivista, crítica do mercado e das instituições reencontrando a aura na política. Esses agentes saem de uma política da arte com ênfase formalista, internalista e estética, para uma política na arte com ênfase nas relações com a sociedade, com os movimentos sociais, com o cenário político de cada grupo e seu contexto relacional específico (BERTOLOSSI, 2015).

Uma anti-arte contra a comodificação, como preconizava o grupo Fluxus nos anos 60 e 70, mas também nos termos de Helio Oiticica, para quem o museu não é mais o cubo branco, mas o mundo. Nessa voga contracultural, Nietzsche, Blanchot, Artaud e Deleuze são usados como toga intelectual e política, e retomados com força, ao lado de Antonio Negri e Michael Hardt, e mais recentemente de Slavoj Zizek para pensar saídas neorromânticas contra o Estado e contra o Mercado em tempo de globalização neoliberal e antropofagia zumbi, diria Suely Rolnik (ROLNIK, 2008).

Tal relação redentora das artes na direção oposta a do seu "karma elitista originário" possui um intenso background na história ocidental, nos mostra Miguel Chaia (CHAIA, 2007). A "arte sem indivíduo" voltada ao partido e ao Estado esteve presente na estética revolucionária comunista/marxista, nos debates sobre forma revolucionária e arte revolucionária, que já permeavam a obra de autores como

${ }^{5}$ Este debate recente tem sido tematizado por uma série de autores curadores, dentre eles, o crítico cubano Gerardo Mosquera (MOSQUERA, 2014, p. 328-338), para quem é necessário pensar em outras estratégicas expositivas que evitem, por exemplo, aproximações entre a consagrada arte do norte do planeta com a ainda bastante exotizada e pouco divulgada arte do sul. Mosquera fala de aproximações e rotas multidirecionais como forma de subverter as hierarquizações da arte latino-americana, além da urgência de superar o conceito de antropofagia como estratégia decolonial diante dos centros de poder euroamericanos, considerando-se que o mesmo já teria sido colonizado e reapropriado de forma identitária por estes centros. 
Maiakóvski e Georges Lukács. A relação entre arte e Estado esteve presente em Thomas Hobbes que via a política como arte e o Leviatã como sua representação artística; questionadas por sua vez por Hannah Arendt que as opunha: arte como trabalho e política como labor. O que importa notar é que a vida, valor tão preconizado no cenário recente, ressurge pela política e o seu entendimento da arte como arena crítica da sociedade, e de seus desdobramentos na politização do campo artístico, assim como na estetização das bandeiras políticas.

Num horizonte reacionário e de caráter fascista, as relações entre arte e política foram perigosas e contra a vida, sugere Chaia, em decorrência da invenção de uma estética em favor de uma política centralizadora, da massificação, propaganda, controle do corpo e disciplinarização da multidão, como aconteceu com o nazi-fascismo $^{6}$ e o stalinismo. O horizonte de uma arte dionisíaca, em favor da vida, presente também (e, sobretudo) em Nietzsche, de alertar as consciências e os corpos e de o artista ser um petardo social, entram em crise e em xeque quando o artista se torna um operário do Estado com sua liberdade cerceada cujas qualidades expressivas são subsumidas em favor de uma ideologia que reifica as instituições burguesas, religiosas e estatais.

No entanto, a transformação da arte em vida, em diferença, e em agenda política parece ter como contrapartida reversa (e moderna) o saudosismo de certa aura/alma perdida, de um sentido mítico originário devassado. Rodrigo Naves (NAVES, 2014) parece se alinhar a Adorno quando afirma que a transformação do artista em homem comum e de tudo em arte tem por perigo o esvaziamento do campo e do debate do crítico, e da subserviência do pensamento artístico ao espetáculo e à indústria da consciência.

\section{Tristeza e redenção}

Uma alternativa crítica a essas encruzilhadas aqui apresentadas e que tem sido recorrente em exposições mundo afora é o interesse por mundos extra-ocidentais ou extra-modernos. Ameríndios, africanos, asiáticos e aborígenes são evocados como a "nova vanguarda" e também tomam a dianteira do processo para afirmar e visibilizar sua entrada num campo ainda desigual e extremamente hierarquizado. Pós-colonialismo e pós-modernismo no pensamento e nas artes, ao lado da inclusão dos agentes fora dos centros de poder euro-americanos vem sendo realizada numa profusão de exposições que tem como pioneiras a mostra "Primitivism in the XXtieth Century" no MoMA, em 1984, e, "Magiciens de la Terre" no Centre Georges Pompidou, em 1989.

A mostra do MoMA, com curadoria do crítico Willian Rubin, tinha por objetivo demonstrar a influência da arte africana na vanguarda cubista. O empreendimento, no entanto, foi bastante criticado por apresentar uma abordagem

\footnotetext{
${ }^{6}$ Alessandra Carvalho (CARVALHO, 1998, p. 171-175) relata que a ideologia e a publicidade nazista, por exemplo, combatia o individualismo burguês e preconizava um retorno ao espírito comunitário, à nação. $A$ dimensão estética na política e na publicidade nazista se deu na pompa e no gigantismo dos comícios, marchas e comemorações do regime na intenção de produzir um sentimento de pertencimento e de renúncia da vontade individual. Eric Hobsbawm (HOBSBAWM, 2013, p. 259-265, p. 266-277) comenta que as vanguardas do centro e do leste da Europa converteram-se em massa para a esquerda revolucionária. Maiakóvski e Malevitch, por exemplo, teriam produzido broadsides patrióticos em 1914. No entanto, quando Stálin sobe ao poder a estética política recupera os símbolos do czarismo como forma de contraposição aos nazistas.
} 
considerada etnocêntrica e racista ao desconsiderar as matrizes e os sentidos sociocosmológicos/cosmopolíticos dos objetos africanos e ao utilizá-los como legendas e ilustrações da genialidade dos artistas ocidentais. A exposição seguinte, realizada anos depois no Pompidou, tinha como intuito responder ou problematizar as questões de sua antecessora americana. Jean Hubert Martin, curador de "Magiciens", optou por uma abordagem pós-moderna, com artistas com autoria individual de sociedades em transição em diversas partes do globo, e uma cenografia escura, mas foi também bastante criticada por ser se assemelhar a um museu etnográfico e incorrer no imaginário exotizante ao selecionar trajetórias fora do mainstream mantendo a lógica da magia e do misticismo para tratar da produção extra-ocidental.

O "mito primitivista", que concebe o outro como criatividade indômita e origem da humanidade, ainda assola o campo das artes e esteve presente em diversas exposições importantes, ora de forma crítica e com a participação de artistas e curadores indígenas em sua concepção conceitual, ora de forma estereotipada e racista . O interesse recente de artistas e curadores no pensamento antropológico de Eduardo Viveiros de Castro (VIVEIROS DE CASTRO, 2002) e o seu perspectivismo ameríndio (com matrizes ocidentais que vão de Nietzsche e Deleuze até os índios Araweté) se inspira na imaginação antropológica deste autor, que sugere a diferença indígena não como outro eu, mas eu outro; outras filosofias e ontologias para além da vã imaginação ocidental. Os riscos deste movimento é a permanência de um olhar evolucionista e estigmatizante alinhado com a antropologia da história ocidental. Se o indígena era visto antes como o passado atrasado da humanidade, ele é agora visto como projeto redentor de futuro.

Em um contexto de novo questionamento do desenvolvimentismo moderno e o seu impacto sobre a natureza e o clima ressurge, portanto, o indianismo como profecia e futurologia alternativa. Diante da crise climática e do Antropoceno, lideranças indígenas importantes no debate ecológico internacional, como o yanomami Davi Kopenawa, são tornados algo como Dalai Lamas indígenas para os anseios narcísicos da arte ocidental. A escolha dos Yanomami, no entanto, não é aleatória. Dentre diversos povos ameríndios, esse povo foi um dos mais devassados pela cobiça antropológica e artística, oscilando entre sua invenção imagística ora como índios violentos e canibais, ora como porta-vozes idílicos da ecologia, verdadeiros

\footnotetext{
${ }^{7}$ Gil Perry (PERRY, 1998) entende o primitivismo artístico como um menor/minoritário na arte moderna. Se o primitivismo científico via os povos extramodernos como reminiscência atrasada, estagnados na barbárie e na natureza no contexto vitoriano, os artistas da vanguarda os viam como livres das amarras e doenças da civilização e das cidades, inteligência estética original, força criativa ilimitada. Os primitivos inspirariam a potência criativa das vanguardas modernas pelo contraste. O autor distingue um "primitivismo de dentro" (loucos, camponeses, ciganos, artistas de circo) de outro "de fora" (povos africanos, oceânicos, japonismo, orientalismo).

${ }^{8}$ Dentre diversas exposições possíveis para debater esta questão, gostaria de mencionar aquelas destacadas pelo sociólogo Laymert Garcia dos Santos (SANTOS, 2010) em seu artigo sobre as interações entre a arte global e a arte étnica. Santos sugere que a exposição "Die Tropen", com curadoria de Alfons Hug, Peter Junge e Viola König, em exibição no Martin-Gropius Bau, em Berlim, em 2008, se equivocou em sua pretensão de aproximar trabalhos artísticos no centro do planeta por manter as hierarquias entre arte contemporânea e objetos indígenas usados como legendas das primeiras, que tem destaque na mostra. Além disso, a exposição não teria contemplado os sentidos sociocosmológicos dos povos ameríndios acerca dos conceitos de arte, natureza e cultura, que são distintos dos ocidentais. Para o sociólogo, uma exposição bem sucedida teria sido "Pollock et le Chamanisme", com curadoria de Stephen Polcari e Marc Restellini, em exibição na Pinacothèque de Paris, em 2008, que apresentou uma abordagem da obra do artista completamente contaminada pelo diálogo/conversão aos valores dos índios norte-americanos e afastada de fetichizações exotizantes e dos clichês do expressionismo abstrato.
} 
bons selvagens ${ }^{9}$.

A permanência da apropriação/expropriação dos mundos indígenas pela arte denota um aspecto problematizado por Hal Foster (FOSTER, 2014) em seu ensaio "O artista como etnógrafo". O crítico americano alerta sobre a essencialização, estigmatização e a apropriação de um outro pós-colonial exotizado, paternalizado e subvertido perversamente aos interesses ideológicos dos agentes artísticos ocidentais que se arrogam a traduzi-lo e/ou serem porta-vozes inspirados em tais poéticas e políticas. Esse tipo de procedimento folclorizante parece retomar vanguardas modernas em seu gosto primitivista e orientalista pelo outro, antes proletário e de esquerda em Walter Benjamin, e agora subalterno, decolonial e interseccional. As diferenças intensivas e instáveis inerentes a cada mundo cultural e artístico singular apropriado, relidos agora como ontologias, passam a servir aos interesses racistas de mercado étnico, arte identitária, e cultura new age que assola parte do campo artístico internacional e nacional.

Seriam os índios alhures uma alternativa ao capitalismo artista e sua feitiçaria? Seria produtivo sustentar o dualismo reducionista modernos versus terranos ${ }^{10}$ como sugerem Bruno Latour e Viveiros de Castro? A aposta na agrobiodiversidade indígena e em suas técnicas de cultivo, e os slogans artísticos em defesa de um capitalismo verde e sustentável manteriam a aura da vida de uma população planetária? Como avaliar essa "guerra de magia" entre atores defensores de uma transcendente arte-vida (que parece ressoar a busca pelo absoluto em Hegel) e aqueles que defendem uma imanente arte-capitalista para colecionismo e outras lógicas de consumo, sem incorrer num moralismo essencialista? Como reinventar as artes da memória para construir outros arquivos disponíveis à manutenção da vida e superar a previsão de apocalipse da arte e do humano, agora sob a alcunha do Antropoceno e de Gaia? Não seria o prognóstico de crise ele mesmo um dos dispositivos de sustentação do capitalismo, conforme sugere o Comitê Invisível (COMITÊ INVISÍVEL, 2016)?

O "outro lado da força" do capitalismo está cheio de aura, apostam autores recentes como os filósofos Isabelle Stengers (STENGERS, 2007) e Gilles Lipovetsky (LIPOVETSKY; SERROY, 2015) e a psicanalista Suely Rolnik (ROLNIK, 2008). A aposta destes autores é que diante da estetização do mundo, tudo vira consumo e ânsia de prazer a ser saciado, uma eterna dessublimação repressiva nos termos de Marcuse. Ver e ser visto, seguido, vencer e permanecer no star system se torna a sina diária de uma cultura neoliberal vazia de subcelebridades profissionais em busca de sucesso e reconhecimento, escravos de estilos de vida e artificados/medicalizados na direção de uma vida selfie extensiva, cool e divertida, uma moralidade fetichista-aceleracionista da felicidade que bem funciona desde que se

\footnotetext{
$\overline{9}$ Sobre as transformações do imaginário ocidental sobre os Yanomami a partir das coleções fotográficas realizadas em expedições por missionários, jornalistas, antropólogos e artistas, ver a dissertação de Valeria Vega (VEGA, 2017). Para acompanhar o debate sobre a crise climática e o fim do mundo do ponto de vista Yanoma$\mathrm{mi}$, as disputas entre os espíritos xapiri que mantém o céu no lugar e a vida em Omama, e a ameaça trazida pela xawara, a fumaça negra que pode fazer o mundo desabar, ver "A Queda do Céu", de Davi Kopenawa e Bruce Albert (KOPENAWA; ALBERT, 2015).

${ }^{10}$ Alinhados com as ideias acerca da intrusão de Gaia de Bruno Latour e Isabelle Stengers, Eduardo Viveiros de Castro e Déborah Danowski (DANOWSKI; VIVEIROS DE CASTRO, 2014) sugerem que a alternativa à catástrofe climática futura é a invenção de um novo humanismo expandido, não-antropomórfico, que estabeleça um novo pacto com a natureza. Estabelece-se, desse modo, um novo grande divisor: os terranos seriam, desse modo, "indígenas", a alternativa às purificações e ao desenvolvimentismo dos modernos "humanos", também eventualmente chamados de euroamericanos por estes autores (DANOWSKI; VIVEIROS DE CASTRO, 2014, p. 142).
} 
mantenha a lógica produtiva.

Tal approach moralista e pessimista do consumo não considera, no entanto, as perspectivas singulares e microscópicas dos agentes em sua microfísica simbólica $^{11}$, em suas antropofagias táticas cotidianas. Perspectiva essa, por sua vez, que parece fazer vista grossa, por exemplo, à ocidentalização dos mundos indígenas e seu renascimento através de o que Marshall Sahlins (SAHLINS, 2004) chamou de "capitalismos tribais". Indígenas de diversos continentes possuem seus museus próprios, feiras e bienais de arte contemporânea indígena, e a produção de vídeos vistos e enquadrados como "cinema índio" no rótulo de mercado, analisa Carlos Fausto (FAUSTO, 2011).

Diante do medo da indesejada das gentes, proliferam questões. Seremos os bárbaros tecnizados de que falava Oswald de Andrade (ANDRADE, 2011) em sua utopia antropofágica que entreteve a intelligentsia das elites brancas paulistas? Ou será essa tautologia e teleologia evolucionista e ansiosa do "capitalismo primitivista" na arte a retomada de um futurismo formalista? Como a arte deve enfrentar o debate em torno da "expropriação antropofágica do mercado" e da suposta "redenção extra-moderna primitivista" de uma forma menos maniqueísta e que considere as impurezas kitsch, os híbridos anti-vanguarda e as monstruosidades e abjeções queer para além dos grandes divisores ocidentais?

\section{Referências}

ANDRADE, Oswald de. "A crise da filosofia messiânica”. In: A utopia antropofágica. São Paulo: Globo, 2011. p. 138-215.

APPADURAI, Arjun (org.). A vida social das coisas: As mercadorias sob uma perspectiva cultural. Niterói: EdUFF, 2008.

BELTING, Hans. "Epílogo da arte ou da história da arte"?; "O fim da história da arte e a cultura atual"; "Arte universal e minorias: uma nova geografia da história da arte"; "No espelho da cultura de massas: A rebelião da arte contra a história da arte". In: O fim da história da arte. São Paulo: Cosac Naify, 2012. p. 25-32, p. 33-50, p. 115-130, p. 131-146.

BENJAMIN, Walter. "A obra de arte na era de sua reprodutibilidade técnica". In: Magia e técnica, arte e política: ensaios sobre literatura e história da cultura. São Paulo: Brasiliense, 1994. p. 165-196.

BERTOLOSSI, Leonardo. Arte enquadrada e gambiarra: identidade, circuito e mercado de arte no Brasil (anos 80 e 90). Tese (Doutorado) - Faculdade de Filosofia, Letras e Ciências Sociais, Programa de Pós-Graduação em Antropologia Social, Universidade de São Paulo, São Paulo, 2015. 261 p. Disponível em <http://www.teses.usp.br/teses/disponiveis/8/8134/tde-06082015-133310/pt-br.php> Acesso: 21 junho 2017.

\footnotetext{
${ }^{11} \mathrm{Na}$ direção oposta de um consumismo irracionalista ou de uma abordagem moralista há uma vasta bibliografia sobre antropologia do consumo que recupera as razões simbólicas que o motivam. "O Mundo dos Bens", de Mary Douglas e Baron Isherwood (DOUGLAS; ISHERWOOD, 2006); "A Vida Social das Coisas", de Arjun Appadurai (APPADURAI, 2008); e "Trecos, Troços e Coisas", de Daniel Miller (MILLER, 2013) são algumas das principais referências nesta temática.
} 
_. "Quem foi você, geração 80?: mercado de arte, pintura e hedonismo em questão". In: Ciência hoje. No. 321. Vol. 54. Dezembro de 2014. p. 41-54. Disponível em

$<$ http://assinaturadigital.cienciahoje.org.br/revistas/reduzidas/321/files/assets/basic-

html/index.html\#page1> Acesso: 21 junho 2017.

CARVALHO, Alessandra. "Nazismo: festa e ideologia". In: SILVA, Francisco Carlos Teixeira da (org.). História e imagem. Rio de Janeiro: Pontual, 1998. p. 171-175.

CESAR, Marisa Flórido. As muitas mortes da arte. Texto da palestra homônima da programação da exposição "Depois do futuro" (EAV/Parque Lage, março-maio de 2016). Manuscrito. p. 1-24.

CHAIA, Miguel. "Arte e política: situações". In: CHAIA, Miguel (org.). Arte e política. Rio de Janeiro: Azougue Editorial, 2007. p. 13-39.

DANOWSKI, Déborah; VIVEIROS DE CASTRO, Eduardo. "Humanos e terranos na guerra de Gaia". In: Há mundo por vir? Ensaio sobre os medos e os fins. Desterro: Cultura e Barbárie/Instituto

Socioambiental, 2014. p. 107-142.

DANTO, Arthur. "Introdução: moderno, pós-Moderno e contemporâneo"; "Três décadas após o fim da arte". In: Após o fim da arte: a arte Contemporânea e os limites da história. São Paulo: EDUSP, 2006. p. 3-21, p. 23-43.

DOUGLAS, Mary; ISHERWOOD, Baron. O mundo dos bens: para uma antropologia do consumo. Rio de Janeiro: Editora UFRJ, 2006.

DUARTE, Pedro. "A emergência filosófica da arte"; "O amor entre arte e filosofia". In: Estio do tempo: romantismo e estética moderna. Rio de Janeiro: Jorge Zahar, 2011. p. 27-41, p. 154-166.

EAGLETON, Terry. "O imaginário kantiano". In: A ideologia da estética. Rio de Janeiro: Jorge Zahar, 1993. p. 55-77.

ELIAS, Norbert. Mozart: sociologia de um gênio. Rio de Janeiro: Jorge Zahar, 1995.

ERIBON, Didier; LÉVI-STRAUSS, Claude. "O conteúdo da pintura”. In: De perto e de longe. São Paulo: Cosac Naify, 2005. p. 239-246.

FAUSTO, Carlos. "No registro da cultura: O cheiro dos brancos e o cinema dos índios". In: ARAÚJO, Ana Carvalho Ziller (org.). Vídeo nas aldeias 25 anos. Olinda: Vídeo nas Aldeias, 2011. p. 160-168.

FOSTER, Hal. "O artista como etnógrafo". In: O retorno do real. São Paulo: Cosac Naify, 2014. p. 159185.

HOBSBAWM, Eric. "Arte e Revolução"; "Arte e Poder". In: Tempos Fraturados: Cultura e Sociedade no Século XX. São Paulo: Companhia das Letras, 2013. p. 259-265, p. 266-277. 
GAGNEBIN, Jeanne Marie. "Atenção e dispersão: elementos para uma discussão sobre arte contemporânea"; "De uma estética da visibilidade para uma estética da tatibilidade". In: Limiar, aura e rememoração: ensaios sobre Walter Benjamin. São Paulo: Editora 34, 2014. p. 99-119, p. 155-175.

GELL, Alfred. Art and agency: an anthropological theory. Oxford: Clarendon, 1998.

_. "A rede de Vogel: armadilhas como obras de arte e obras de arte como armadilhas". In: Arte e ensaios: revista do programa de pós-graduação em artes visuais. Rio de Janeiro: Escola de Belas Artes da UFRJ. Ano 8. No. 8. 2001. p. 174-191. Disponível em

$<$ https://pt.scribd.com/document/341381205/alfred-gell-a-rede-de-vogel-armadilhas-como-obras-de-artee-obras-de-arte-pdf> Acesso: 21 junho 2017.

INVISÍVEL, Comitê. "Merry crisis and happy new fear". In: Aos nossos amigos: crise e insurreição. São Paulo: N-1 Edições, 2016.

KOPENAWA, Davi; ALBERT, Bruce. A queda do céu: palavras de um xamã Yanomami. São Paulo: Companhia das Letras, 2015.

LATOUR, Bruno. Jamais fomos modernos: ensaio de antropologia simétrica. Rio de Janeiro: Editora 34, 1994

_. "O que é iconoclash? Ou, há um mundo além da guerra de imagens"? In: Horizontes antropológicos. Porto Alegre. Ano 14. No. 29. Jan./jun. 2008. p. 111-150. Disponível em <http://www.scielo.br/pdf/ha/v14n29/a06v14n29.pdf> Acesso: 21 junho 2017.

LÉVI-STRAUSS, Claude. "A ciência do concreto". In: O pensamento selvagem. Campinas: Papirus, 1989. p. $15-49$.

_. "Introdução à obra de Marcel Mauss". In: MAUSS, Marcel. Sociologia e antropologia. São Paulo: Cosac Naify, 2003. p. 11-46.

_. "Olhares sobre os objetos”. In: Olhar, escutar, ler. São Paulo: Companhia das Letras, 1997. p. 139140.

LIPOVETSKY, Gilles; SERROY, Jean. "O capitalismo artista”. In: A estetização do mundo: Viver na era do capitalismo artista. São Paulo: Companhia das Letras, 2015. p. 39-129.

MARX, Karl. "O fetichismo da mercadoria”. In: O capital. São Paulo: Abril Cultural, 1983. p. 70-78.

MAUSS, Marcel. "Esboço de uma teoria geral sobre a magia". In: Sociologia e antropologia. São Paulo: Cosac Naify, 2003. p. 47-181.

MILLER, Daniel. Trecos, troços e coisas: estudos antropológicos sobre a cultura material. Rio de Janeiro: Zahar, 2013. 
MOSQUERA, Gerardo. "Além da antropofagia: arte, internacionalização e dinâmica cultural”. In: SCHWARCZ, Lilia; PEDROSA, Adriano. Histórias mestiças: antologia de textos. São Paulo: Cobogó, 2014. p. 328-338.

NAVES, Rodrigo. "Ainda sobre arte e vida". In: A calma dos dias. São Paulo: Companhia das Letras, 2014. p. 85-89.

NOVAES, Sylvia Caiuby. "Lévi-Strauss: razão e sensibilidade". In: Revista de antropologia. Vol. 42. Nos. 1-2. 1999. Disponível em <http://www.scielo.br/scielo.php?script=sci_arttext\&pid=S0034-

$77011999000100005>$ Acesso: 21 junho 2017.

PERRY, Gill. “O primitivismo e o "moderno””. In: PERRY, Gill et alli (orgs.). Primitivismo, cubismo, abstração. São Paulo: Cosac Naify, 1998. p. 3-30.

PRICE, Sally. Arte primitiva em centros civilizados. Rio de Janeiro: Editora UFRJ, 2000.

ROLNIK, Suely. "Antropofagia zumbi”. In: COHN, Sergio; CESARINO, Pedro; REZENDE, Renato (orgs.). Azougue: edição especial 2006-2008. Rio de Janeiro: Beco do Azougue, 2008. p. 203-220.

ROSENBERG, Harold. Objeto ansioso. São Paulo: Cosac Naify, 2004.

SAHLINS, Marshall. "A tristeza da doçura ou a antropologia nativa da cosmologia ocidental”. In: Cultura na Prática. Rio de Janeiro: Editora UFRJ, 2004. p. 563-619.

_. "Digressão: baleias brancas mortas, ou da leviatanologia à subjetologia. In: História e cultura: apologias à Tucídides. Rio de Janeiro: Jorge Zahar, 2006. p. 133-148.

_. "O que é o iluminismo antropológico?" In: Cultura na prática. Rio de Janeiro: Editora UFRJ, 2004. p. 535-562.

SANTOS, Laymert Garcia dos. "Como a arte global transforma a arte étnica”. In: Depois do muro. Recife: Fundação Joaquim Nabuco/Massangana, 2010. p. 11-45.

STENGERS, Isabelle. La sorcellerie capitaliste: pratiques de désenvoûtement. Paris: La Découverte, 2007.

VEGA, Valeria Alejandra Pérez. Imagens sem pele e esquecimento Yanomami: restituição e autorrepresentação na conformação de um modelo de arquivo fotográfico. Dissertação (Mestrado) Escola de Belas Artes, Programa de Pós-Graduação em Artes Visuais, Universidade Federal do Rio de Janeiro, Rio de Janeiro, 2017. 157 p.

VIVEIROS DE CASTRO, Eduardo. "Perspectivismo e multinaturalismo na América Indígena". In: A inconstância da alma selvagem. São Paulo: Cosac Naify, 2002. p. 345-399. 
WAGNER, Roy. A invenção da cultura. São Paulo: Cosac Naify, 2010.

WEINER et alli. "Aesthetics is a cross-cultural category"? In: INGOLD, Tim (ed). Key debates in anthropology. New York: Routledge, 1996. p. 251-293.

Recebido em 15/06/2017 - Aprovado em 21/08/2017 